\title{
Soil microbial biomass and community composition along an anthropogenic disturbance gradient within a long-leaf pine habitat
}

\author{
A.D. Peacock ${ }^{\mathrm{a}, *}$, S.J. Macnaughton ${ }^{\mathrm{b}}$, J.M. Cantu ${ }^{\mathrm{a}}$, V.H. Dale ${ }^{\mathrm{c}}$, D.C. White ${ }^{\mathrm{a}}$ \\ ${ }^{a}$ Center for Biomarker Analysis, 10515 Research Drive Suite 300, The University of Tennessee, Knoxville, TN 37932, USA \\ b AEA Technology Environment, Building 156, Harwell, OXON, OX11 OBR, UK \\ ${ }^{\mathrm{c}}$ Environmental Sciences Division Oak Ridge National Laboratory, P.O. Box 2008, Oak Ridge, TN 37831-6036, USA
}

Accepted 18 December 2001

\begin{abstract}
Some of the finest surviving natural habitat in the United States is on military reservations where land has been protected from development. However, responsibilities of military training often require disturbance of that habitat. Herein, we show how the soil microbial community of a long-leaf pine ecosystem at Fort Benning, Georgia responds to military traffic disturbances. Using the soil microbial biomass and community composition as ecological indicators, reproducible changes showed increasing traffic disturbance decreases soil viable biomass, biomarkers for microeukaryotes and Gram-negative bacteria, while increasing the proportions of aerobic Gram-positive bacterial and Actinomycete biomarkers. Soil samples were obtained from four levels of military traffic (reference, light, moderate, and heavy) with an additional set of samples taken from previously damaged areas that were remediated via planting of trees and ground cover. Utilizing 17 phospholipid fatty acid (PLFA) variables that differed significantly with land usage, a linear discriminant analysis with cross-validation classified the four groups. Wilks' lambda for the model was $0.032(P<0.001)$. Overall, the correct classifications of profiles was $66 \%$ (compared to the chance that $25 \%$ would be correctly classified). Using this model, 10 observations taken from the remediated transects were classified. One observation was classified as a reference, three as light trafficked, and six as moderately trafficked. Non-linear artificial neural network (ANN) discriminant analysis was performed using the biomass estimates and all of the 61 PLFA variables. The resulting optimal ANN included five hidden nodes and resulted in an $r^{2}$ of 0.97 . The prediction rate of profiles for this model was again $66 \%$, and the 10 observations taken from the remediated transects were classified with four as reference (not impacted), two as moderate, and four as heavily trafficked. Although the ANN included more comprehensive data, it classified eight of the 10 remediated transects at the usage extremes (reference or heavy traffic). Inspection of the novelty indexes from the prediction outputs showed that the input vectors from the remediated transects were very different from the data used to train the ANN. This difference suggests as a soil is remediated it does not escalate through states of succession in the same way as it descends following disturbance. We propose to explore this hysteresis between disturbance and recovery process as a predictor of the resilience of the microbial community to repeated disturbance/recovery cycles. @ 2001 Elsevier Science Ltd. All rights reserved.
\end{abstract}

Keywords: Phospholipid fatty acid (PLFA); Habitat disturbance; Recovery; Artificial neural network (ANN)

\footnotetext{
* Corresponding author. Present address: Center for Biomarker Analysis, The University of Tennessee, 10515 Research Drive Suite 300, Knoxville, TN 37932-2575, USA. Tel.: +1-865-974-8014; fax: +1-865-974-8027.

E-mail address: apeacock@utk.edu (A.D. Peacock).
}

\section{Introduction}

Managers at military installations provide land for training of military personnel. Often, such activities are inconsistent with sustainable land use practices. 
An effective monitoring program capable of predicting recovery from training use is essential to ensuring the long-term viability of these lands. Previously, the majority of these monitoring programs have focused on biodiversity of terrestrial macroorganisms that have a long period of recovery and require expensive monitoring specialists. Microorganisms that can be quantitatively monitored with chemical biomarkers have been largely overlooked despite their complete integration and dependency with the macroworld (Zak et al., 1994; Lee, 1991).

Microbial biomass in soil has a turnover time of less than a year and can react quickly to conditions of nutrients, moisture, temperature and the type and amount of soil organic matter levels (Paul, 1984). Viable microbial biomass is integral for nutrient storage and cycling (Rice et al., 1996), soil aggregate formation (Tisdall and Oades, 1982), and other ecological factors such as filtering, buffering, and gene reserves (Blum, 1998). Soil microbial biomass and community composition have been shown to be sensitive indicators of changes in nutrient type (Peacock et al., 2001; Kirchner et al., 1993), botanical composition (Borga et al., 1994), pollutant toxicity (Stephen et al., 1999), and climate change (Zogg et al., 1997). Because the microbial community integrates the physical and chemical aspects of the soil and responds to anthropogenic activities, it can be considered a biological indicator of soil quality (Rice et al., 1996). The microbial viable biomass, community composition, and nutritional status can be readily measured by analysis of extracted lipids to provide rational endpoints for many disturbance/recovery processes (White et al., 1998).

In this study, we investigated the utility of using the soil microbial biomass and community composition as ecological indicators of change along an anthropogenic disturbance gradient. The disturbance gradient included the duration and type of traffic in military training areas in a long-leaf pine habitat. The hypothesis was that duration and intensity of disturbance (traffic) in the long-leaf pine ecosystem would be reflected in changes in the soil microbial community biomass and structure. These changes could be quantitatively measured by phospholipid ester-linked fatty acid analysis (PLFA). In addition, we used two different data analysis techniques to classify disturbance, the first, a linear discriminant analysis classified transects based on 17 PLFA variables, the second, a non-linear artificial neural network analysis which included all 61 PLFA variables and the biomass in which to base predictions. Herein, we compare these two analyses.

\section{Materials and methods}

\subsection{Study site}

This study was conducted at the Fort Benning Army Installation located in the lower Piedmont Region and lower coastal plane of central Georgia and Alabama, near Columbus, Georgia. The post consists of approximately 73,650 ha of river valley terraces and rolling terrain. The climate at Fort Benning is humid and mild with rainfall occurring regularly throughout the year. Annual precipitation averages $105 \mathrm{~cm}$ with October being the driest month. The majority of the soils at the installation are heavily weathered Ultisols.

This study encompased training areas that have been subjected to a range of military traffic. Disturbance of the soil ecosystem due to training includes the direct removal or damage of terrestrial vegetation, digging activities, dislocation, and compaction from vehicles, erosion, and sedimentation. The degree and extent of the impacts of training activities within a compartment are dependent upon the type of activity, number of personnel training, and how frequently the compartment is exposed to activity. Furthermore, training activity typically occurs irregularly throughout a compartment, creating localized gradients of disturbance within individual compartments.

\subsection{Soil sampling}

Soil cores were collected in the Autumn of 1999. To avoid cross contamination in between each sample, the soil cores were washed in solvent (methanol) and sterile distilled water. Cores were approximately $20 \mathrm{~cm}$ in length and $2 \mathrm{~cm}$ in width. For each core taken, the depth of the core and the presence/absence of an "A" horizon was reported. Five samples were taken from separate plots at each transect ( 14 transects $\times 5=70$ samples, Table 1). Of the transects selected, three were reference transects (with stand ages 28, 68, and 74 years); three were heavy usage (undergoing tracked vehicle training); three were moderate usage (areas adjacent to tracked vehicle training); three were 
Table 1

Sample design

\begin{tabular}{lll}
\hline Transect & $\begin{array}{l}\text { Number of } \\
\text { samples }\end{array}$ & Disturbance \\
\hline A & 5 & Reference \\
E & 5 & Reference \\
M & 5 & Reference \\
D & 5 & Light \\
L & 5 & Light \\
N & 5 & Light \\
C & 5 & Moderate \\
I & 5 & Moderate \\
K & 5 & Moderate \\
B & 5 & Heavy \\
H & 5 & Heavy \\
J & 5 & Heavy \\
F & 5 & Remediated \\
G & 5 & Remediated \\
\hline
\end{tabular}

light usage (infantry training), and two came from a site currently undergoing remediation (previous heavy disturbance, currently trees and groundcover planted and no usage). Samples were stored at $-80^{\circ} \mathrm{C}$ prior to analysis.

\subsection{PLFA analysis}

PLFA analysis was performed using previously reported precautions (White and Ringelberg, 1998). Soil samples ( $5 \mathrm{~g}$ ) were extracted with the single-phase chloroform-methanol buffer system of Bligh and Dyer, 1954, as modified (White et al., 1979). The total lipid extract was fractionated into neutral lipids, glycolipids, and polar lipids by silicic acid column chromatography (Guckert et al., 1985). All results presented in this paper are for the polar lipid fraction. The polar lipids were transesterified to the fatty acid methyl esters (FAMEs) by a mild alkaline methanolysis (Guckert et al., 1985).

The FAMEs were analyzed by capillary gas chromatography with flame ionization detection on a Hewlett-Packard 5890 series 2 chromatograph with a $50 \mathrm{~m}$ non-polar column $(0.2 \mathrm{~mm}$ i.d., $0.11 \mu \mathrm{m}$ film thickness). Preliminary peak identification was performed by comparison of retention times with known standards. Definitive identification of peaks was accomplished by gas chromatography/mass spectroscopy of selected samples using a Hewlett-Packard 6890 series gas chromatograph interfaced to a
Hewlett-Packard 5973 mass selective detector using a $20 \mathrm{~m}$ non-polar column $(0.1 \mathrm{~mm}$ i.d., $0.1 \mu \mathrm{m}$ film thickness).

Fatty acids are named according to the convention $X: Y \omega Z$, where " $X$ " stands for the number of carbon atoms in the chain, " $Y$ " for the number of unsaturations, and ' $Z$ ' the number of carbon atoms from the terminal methyl end of the molecule to the first unsaturation encountered. Prefixes; " $\mathrm{i}$ " $\equiv i s o$-branched, "a" 三anteiso-branched, "10me" =methyl branch on the 10th carbon from the carboxylate end, "Br" $\equiv$ branched at unknown location, and "Cy" $\equiv$ cyclopropyl. The suffixes " $\mathrm{c}$ " and " $\mathrm{t}$ " stand for the cis and trans, geometric isomers of the unsaturation, respectively. When different fatty acids had the same designation, they were distinguished by lower case letters suffixes $a, b$, etc. (Gunstone and Herslöf, 1992).

\subsection{Statistical analysis}

Biomass (pmol/g PLFA) and relative proportion $(\mathrm{mol} \%)$ of specific PLFA were used to test the null hypothesis that degree of land disturbance would not influence the composition of the soil microbial communities. To test that hypothesis, an analysis of variance (ANOVA) using the General Linear Model STATISTICA procedure (Statsoft Inc., Tulsa, OK) for a completely randomized design with five treatments was used. The values reported are least square means of 15 replicates, except in the case of the remediated treatment which contained 10 replicates (total $n=70$ ). Standard errors of the means were determined. Differences in the mean proportions of PLFA in each treatment were tested using Tukey's Honest-Significant-Difference procedure. A hierarchical cluster analysis (Ward's method, 1-Pearson $r$ ) was used to discover how the PLFAs that differed significantly with treatment were clustered.

A linear discriminant analysis with cross-validation (SAS Institute Cary, NC) was chosen to classify the observations into one of the four usage classes $(n=$ 60,15 observations in each group) based on the degree of land disturbance. Only those PLFA that comprised at least $1 \%$ of any profile were included in the analysis. Therefore, fatty acids that may have been unreliably quantified were not included. Before statistical analysis, arcsine square root transformation was applied 
to the mol\% PLFA data. After truncation, a one-way ANOVA was conducted on the remaining PLFAs, and those that differed significantly with usage were included in the model.

\subsection{Artificial neural network analysis}

Neural network identification was performed with early stopping by cross-validation and topology optimization by bootstrapping (selection criteria; median cross-validated error), using microcortex web based neural computing environment (www.microcortex. com).

\section{Results}

Degree of land use resulted in a significant difference in the microbial biomass estimates (PLFA), for the highly trafficked soil $(P<0.05$, Fig. 1$)$. If it is assumed that 1 pmol of PLFA is equivalent to $2.5 \times 10^{4}$ bacterial cells (Balkwill et al., 1988; Pinkart et al., 2000 ), then bacterial density in the soils ranged from approximately $7.7 \times 10^{8}$ cells $^{-1}$ in the reference soil to $3.8 \times 10^{7}$ cells g $^{-1}$ in the heavily trafficked soil.
The soil currently undergoing restoration contained an average of $5.8 \times 10^{8}$ cells g $^{-1}$.

PLFA analysis identified 61 fatty acids all of which are commonly found in soil environments (Peacock et al., 2001). Of the 61 fatty acids detected and quantified, 28 were highly significant according to a one-way ANOVA $(P<0.001)$. Mean separations were conducted on the 28 PLFAs using Tukey's Honest-Significant-Difference procedure and the results are presented in Table 2. Generally, the short-chain normal saturated PLFA (14:0, 15:0, and 16:0) decreased with increasing traffic, while the longer chain normal saturated PLFA (18:0 and 20:0) increased with increasing traffic. Monounsaturated and polyunsaturated PLFAs decreased with increasing traffic, whereas the methyl-branched saturated PLFAs increased with increasing traffic. An exploratory hierarchical cluster analysis (Ward's method, 1-Pearson $r$ ) was conducted using the 28 highly significant variables (Fig. 2). Two primary clusters emerged. The first contained predominantly short-chain saturated, monounsaturated, and polyunsaturated PLFA, while the second contained long-chain saturates, methyl-branched monounsaturated, and saturated PLFA. A secondary cluster derived from the first

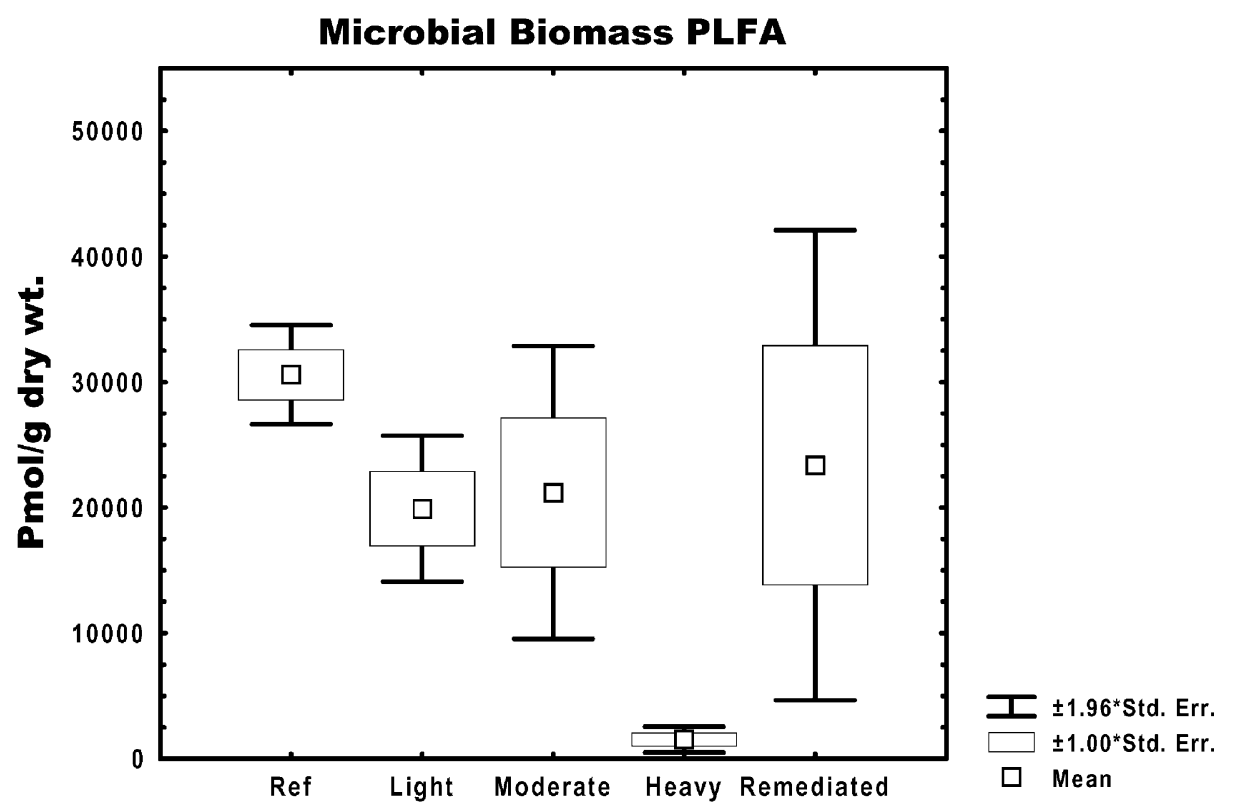

Fig. 1. Microbial biomass PLFA of samples from the four disturbance categories and samples undergoing remediation. The reference samples contain the highest microbial biomass followed by light and moderate disturbance and finally heavy disturbance. 
Table 2

Mean relative proportions of PLFAs by treatment

\begin{tabular}{|c|c|c|c|c|c|}
\hline PLFA & Reference & Light & Moderate & Heavy & Remediated \\
\hline \multicolumn{6}{|l|}{ General } \\
\hline $14: 0$ & $0.53 \mathrm{a}$ & $0.50 \mathrm{a}$ & $0.46 \mathrm{a}$ & $0.18 \mathrm{~b}$ & $0.40 \mathrm{a}$ \\
\hline $15: 0$ & $0.65 \mathrm{a}$ & $0.57 \mathrm{a}$ & $0.58 \mathrm{a}$ & $0.26 \mathrm{~b}$ & $0.51 \mathrm{a}$ \\
\hline $16: 0$ & $12.8 \mathrm{a}$ & $12.81 \mathrm{a}$ & $13.31 \mathrm{a}$ & $10.08 \mathrm{~b}$ & $13.31 \mathrm{a}$ \\
\hline 18:0 & $3.04 \mathrm{c}$ & $3.47 \mathrm{c}$ & $4.20 \mathrm{~b}$ & $5.12 \mathrm{a}$ & $3.42 \mathrm{c}$ \\
\hline $20: 0$ & $0.96 \mathrm{~b}$ & $0.81 \mathrm{~b}$ & $1.06 \mathrm{~b}$ & $1.63 \mathrm{a}$ & $0.76 \mathrm{~b}$ \\
\hline \multicolumn{6}{|c|}{ Gram-negative bacteria } \\
\hline $15: 1$ & $0.08 \mathrm{a}$ & $0.09 \mathrm{a}$ & $0.09 \mathrm{a}$ & $0.02 \mathrm{~b}$ & $0.06 \mathrm{ab}$ \\
\hline $16: 1 w 7 \mathrm{c}$ & $2.79 \mathrm{a}$ & $2.57 \mathrm{ac}$ & $2.29 \mathrm{bc}$ & $1.99 \mathrm{~b}$ & $2.73 \mathrm{ac}$ \\
\hline $16: 1 w 5 \mathrm{c}$ & $1.9 \mathrm{a}$ & $1.82 \mathrm{a}$ & $1.96 \mathrm{a}$ & $1.52 \mathrm{a}$ & $2.49 \mathrm{~b}$ \\
\hline $17: 1$ & $0.16 \mathrm{ab}$ & 0.18 a & $0.10 \mathrm{~b}$ & $0.06 \mathrm{c}$ & $0.11 \mathrm{abc}$ \\
\hline $18: 1 w 5 \mathrm{c}$ & $0.89 \mathrm{a}$ & $0.96 \mathrm{a}$ & $0.89 \mathrm{a}$ & $0.35 \mathrm{~b}$ & $0.95 \mathrm{a}$ \\
\hline Сy19:0 & $12.84 \mathrm{a}$ & $13.53 \mathrm{a}$ & $10.33 \mathrm{~b}$ & $11.34 \mathrm{ab}$ & $8.92 \mathrm{~b}$ \\
\hline \multicolumn{6}{|c|}{ Eukaryote (plant and fungal) } \\
\hline $18: 2 w 6$ & $5.74 \mathrm{a}$ & $5.90 \mathrm{a}$ & $3.63 \mathrm{~b}$ & $1.00 \mathrm{c}$ & $6.51 \mathrm{a}$ \\
\hline $18: 1 w 9 \mathrm{c}$ & $8.49 \mathrm{a}$ & $8.32 \mathrm{a}$ & $7.79 \mathrm{a}$ & $6.08 \mathrm{~b}$ & $8.71 \mathrm{a}$ \\
\hline $20: 3 w 3$ & $0.08 \mathrm{a}$ & $0.09 \mathrm{a}$ & $0.07 \mathrm{ab}$ & $0.01 \mathrm{~b}$ & $0.08 \mathrm{a}$ \\
\hline 20sat & $2.08 \mathrm{a}$ & $2.08 \mathrm{a}$ & $1.32 \mathrm{~b}$ & $0.00 \mathrm{~b}$ & $0.01 \mathrm{~b}$ \\
\hline poly 20 a & $0.13 \mathrm{a}$ & $0.16 \mathrm{a}$ & $0.03 \mathrm{~b}$ & $0.02 \mathrm{~b}$ & $0.02 \mathrm{~b}$ \\
\hline poly $20 \mathrm{~b}$ & $0.18 \mathrm{ab}$ & $0.34 \mathrm{a}$ & $0.28 \mathrm{a}$ & $0.07 \mathrm{~b}$ & $0.35 \mathrm{a}$ \\
\hline \multicolumn{6}{|c|}{ Actinomycetes type } \\
\hline i14:0 & $0.19 \mathrm{a}$ & $0.13 \mathrm{a}$ & $0.15 \mathrm{a}$ & $0.03 \mathrm{~b}$ & $0.19 \mathrm{a}$ \\
\hline br16:0 a & $0.80 \mathrm{~b}$ & $1.06 \mathrm{~b}$ & $1.23 \mathrm{~b}$ & $3.89 \mathrm{a}$ & $0.92 \mathrm{~b}$ \\
\hline br16:0 b & $0.16 \mathrm{a}$ & $0.12 \mathrm{a}$ & $0.07 \mathrm{ab}$ & $0.01 \mathrm{~b}$ & $0.07 \mathrm{ab}$ \\
\hline i16:0 & $3.22 \mathrm{ab}$ & $2.84 \mathrm{~b}$ & $3.86 \mathrm{a}$ & $3.36 \mathrm{ab}$ & $3.51 \mathrm{ab}$ \\
\hline i17:1w7 c & $1.44 \mathrm{~b}$ & $1.49 \mathrm{ab}$ & $1.82 \mathrm{a}$ & $1.73 \mathrm{ab}$ & $1.6 \mathrm{ab}$ \\
\hline 10me16:0 & $3.87 \mathrm{~b}$ & $3.96 \mathrm{~b}$ & $4.46 \mathrm{ab}$ & $4.82 \mathrm{a}$ & $4.13 \mathrm{ab}$ \\
\hline i17:0 & $2.17 \mathrm{c}$ & $2.24 \mathrm{c}$ & $3.76 \mathrm{~b}$ & $4.79 \mathrm{a}$ & $2.95 \mathrm{c}$ \\
\hline a17:0 & $2.14 \mathrm{~b}$ & $2.10 \mathrm{~b}$ & $2.70 \mathrm{a}$ & $2.96 \mathrm{a}$ & $2.67 \mathrm{a}$ \\
\hline 17:0 & $0.64 \mathrm{c}$ & $0.71 \mathrm{bc}$ & $0.76 \mathrm{~b}$ & $0.88 \mathrm{a}$ & $0.67 \mathrm{bc}$ \\
\hline i10me16:0 & $1.26 \mathrm{c}$ & $1.34 \mathrm{c}$ & $3.35 \mathrm{~b}$ & $6.04 \mathrm{a}$ & $1.93 \mathrm{c}$ \\
\hline 12me18:0 & $0.68 \mathrm{c}$ & $0.66 \mathrm{c}$ & $1.45 \mathrm{~b}$ & $2.43 \mathrm{a}$ & $1.48 \mathrm{~b}$ \\
\hline
\end{tabular}

Treatments followed by the same letter are not significant at $\alpha=$ 0.05 .

primary cluster contained short-chain normal saturated and 16 carbon monounsaturates. The remaining secondary clusters contained mostly 18-20 carbon monoand polyunsaturates. Secondary clusters derived from the second primary cluster included long-chain normal saturates and methyl-branched fatty acids.

A linear discriminant analysis with cross-validation was chosen to classify the observations into one of four classes ( $n=60,15$ observations in each group) based on the degree of land disturbance. The first task was to reduce the number of variables to be included in the model. Only those PLFA that comprised at least $1 \%$ of any profile were included in the analysis;
Table 3

PLFAs included in the discriminant model

\begin{tabular}{lll}
\hline a15:0 & i17:0 & $18: 1 \mathrm{w} 9 \mathrm{c}$ \\
$\mathrm{i} 1: 0$ & $\mathrm{a} 17: 0$ & $18: 0$ \\
$16: 1 \mathrm{w} 7 \mathrm{c}$ & Cy17:0 & $10 \mathrm{me} 18: 0$ \\
br16:0 a & $17: 0$ & Cy19:0 \\
i17:1w7 c & i10me16:0 & 20 sat \\
$10 \mathrm{mel6}: 0$ & $18: 2 \mathrm{w} 6$ & \\
\hline
\end{tabular}

therefore, fatty acids that may have been unreliably quantified were not included. Before statistical analysis arcsine square root transformation was applied to the mol\% PLFA data. After this truncation, a one-way ANOVA was conducted on the remaining PLFAs, and those that differed significantly with usage were included in the model. The resulting model included 17 descriptor variables (Table 3). Wilks' lambda for the model was $0.32(P<001)$. Overall, the error estimates for the model were $33 \%$ and the generalized distance between groups is reported in Table 4. Only the first four treatments were used to construct the model. Once the model was complete, the 10 observations taken from the remediated transects were classified. One observation was classified as a reference, three as lightly trafficked, and six as moderately trafficked.

A non-linear artificial neural network discriminant analysis (ANN) was performed using the biomass estimates and all of the 61 PLFA variables. The resulting ANN included five hidden nodes and resulted in an $r^{2}$ of 0.97 . The correct classification of profiles for this model was $66 \%$, and six of the PLFAs had sensitivity values above $3 \%$. As with the linear discriminant model, once the ANN model was complete, it was used to classify the observations from the remediated transects. Four of the observations were classified as reference, two as moderate, and four as heavily trafficked.

\section{Discussion}

The four categories of traffic in this study varied in the amount and diversity of the floristic component (Dale and Beyeler, 2001). In addition, soil carbon and nitrogen concentrations and stocks as well as the carbon to nitrogen ratios, differed significantly with degree of traffic (Garten et al., 2001). Soil compaction due to the amount of traffic was also significantly 
Tree Diagram for 28 PLFA Variables

Ward's method

1-Pearson r

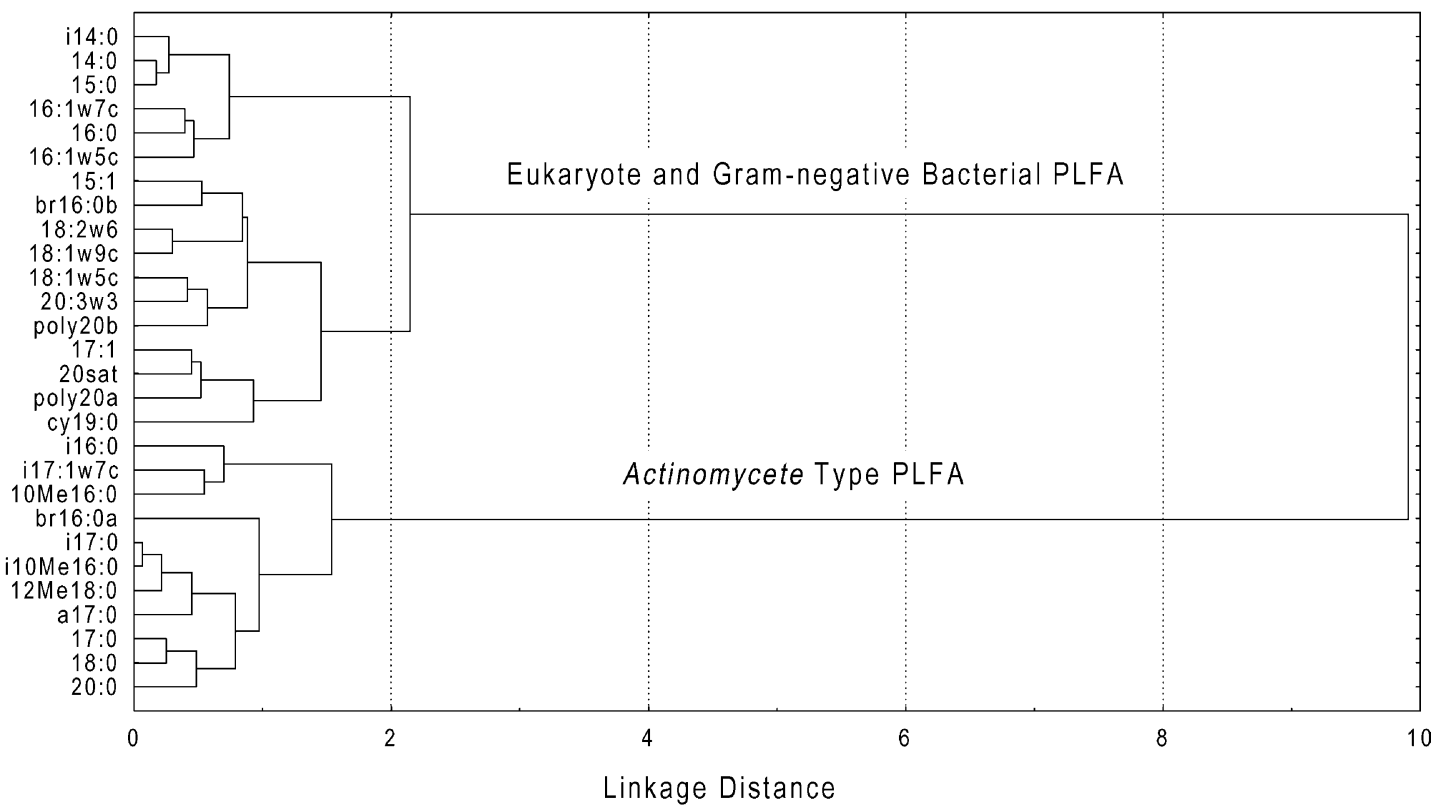

Fig. 2. Cluster analysis of significant PLFA variables (mol\%). Two primary clusters emerged, the first contained primarily PLFAs indicative of eukaryote microorganisms (polyunsaturates) and Gram-negative bacteria (monounsaturates). While the second contained PLFA indicative of the Actinomycetes (methyl-branched saturates).

different along the disturbance gradient (Garten et al., 2001).

Myers et al., 2001 states, "microbial metabolism in soil is limited by the availability and types of organic substrates, and therefore it is plausible that ecosystems which differ floristically will produce litter with chemically distinct substrates that will differentially foster microbial growth." Soil microbial community

Table 4

Number of observations and percent classified into usage

\begin{tabular}{|c|c|c|c|c|c|}
\hline & Reference & Light & Moderate & Heavy & Total \\
\hline Reference $(\%)$ & $11(73.33)$ & $4(26.67)$ & $0(0)$ & $0(0)$ & $15(100)$ \\
\hline Light $(\%)$ & $6(40)$ & $8(53.33)$ & $1(6.67)$ & $0(0)$ & $15(100)$ \\
\hline Moderate & $0(0)$ & $2(13.33)$ & $11(73.33)$ & $2(13.33)$ & $15(100)$ \\
\hline Heavy & $0(0)$ & $1(6.67)$ & $4(26.67)$ & $10(66.67)$ & $15(100)$ \\
\hline \multicolumn{6}{|c|}{ Error count estimates } \\
\hline Rate $(\%)$ & 26.6 & 46.6 & 26.6 & 33.3 & 33.3 \\
\hline Priors $(\%)$ & 25 & 25 & 25 & 25 & \\
\hline \multicolumn{6}{|c|}{ Generalized squared distance } \\
\hline Reference & 0 & 5.65 & 40.47 & 77.8 & \\
\hline Light & 5.65 & 0 & 23.22 & 52.95 & \\
\hline Moderate & 40.47 & 23.22 & 0 & 11.85 & \\
\hline Heavy & 77.8 & 52.95 & 11.85 & 0 & \\
\hline
\end{tabular}


composition and biomass differed along the gradient as measured by the PLFA analysis. Biomass content in these soils decreased with increasing traffic and was significantly lower in highly trafficked soil (Fig. 1). Specific PLFA components can be related to certain subsets of the microbial community, and PLFA patterns can be used to define changes in the community composition. Using the ANOVA results (Table 2), the reference and the lightly trafficked soil contained on average more PLFAs indicative of eukaryotes (including plant associated PLFAs) and Gram-negative bacteria (Wilkinson, 1988), whilst the more trafficked soils contained relatively more PLFAs associated with Actinomyctes (O'Leary and Wilkinson, 1988; Verma and Khuller, 1983). The HCL analysis (Fig. 2) using variable clustering, illustrates this point. Over the disturbance gradient, when PLFA markers for eukaryotes and Gram-negative bacteria were high the PLFAs indicative of the Actinomycetes were low. Monounsaturated PLFAs are indicative of predominantly Gram-negative bacteria (White et al., 1996). An increase in the amount and type of carbon sources has been shown to increase monounsaturated PLFAs (Peacock et al., 2001; Bossio and Scow, 1998; Macnaughton et al., 1999). The loss of monounsaturated PLFAs with traffic indicates a loss of these types of bacteria. Terminally branched saturated PLFA in aerobic environments are indicative of Gram-positive bacteria, including Arthrobacter and Bacillus spp. (White et al., 1996). Many of these types of bacteria can be spore formers and can exist in environments that are lower in overall organic carbon content and higher metabolic refractiveness (Boylen and Ensign, 1970; Keynan and Sandler, 1983). Mid-chain branched saturated PLFA are primarily indicative of Actinomycete type bacteria in surface soils. It has been stated that since these bacteria grow conidia, they are able to better survive in relatively harsh soil environments (desiccation and heat). This may give these bacteria a competitive advantage in the heavily trafficked areas (Alexander, 1998). Polyunsaturated PLFA, shows significant decreases due to traffic and indicates the loss of fungi and microbial grazers that follows the loss of bacterial microorganisms.

Analysis of the soil microbial community PLFA in a predictive linear discriminant model was successful in distinguishing the amount of traffic a soil received. Inspecting the generalized squared distance results from the linear discriminant analysis revealed that the reference and lightly trafficked soils were very close in terms of the microbial community composition (Table 4). In comparison, the moderate and heavily trafficked soils were very different. Indeed, when observations were classified during model validation, most of the misclassifications were between the reference and lightly trafficked soils.

To more fully explore the relationships between the soil disturbance and the microbial community composition, without assumptions of normal distributions or linear relationships, a non-linear artificial neural network discriminant model was applied to the data. The overall predictive effectiveness for correct profile classification for the model was $66 \%$, which was the same for the linear discriminant model. However, the ANN was constructed and optimized using all of the 61 PLFAs and included the biomass parameter. As with the linear analysis, most of the misclassifications occurred between traffic categories that were close (i.e. moderate being classified as heavy). However, when the ANN was used to predict the status of the remediated transects, eight of the 10 samples were classified as either reference or heavy traffic. Inspection of the novelty indexes from the prediction outputs showed that the input vectors from the remediated transects were very different from the data used to train the ANN. This result is not surprising, as when the soil is remediated, it does not escalate through states of succession in the same way it descended by disturbance. In other words, in this case there is not a sliding scale on which the ecosystem recovery can be measured, but a new community succession is taken, initiated by the remediation efforts (planting of groundcover and trees). We propose to further explore this hysteresis between disturbance and recovery process in the microbiota by coupling the lipid biomarker analysis to the specific analysis of community DNA. DNA analyzed by PCR of rDNA with separation of components comprising $>1 \%$ of the community by denaturing gradient gel electrophoresis (DGGE) for sequencing and identification adds more specificity to the quantitative analysis of the lipids. This provides a much clearer model of disturbance and recovery from pollution than either analysis done separately (Stephen et al., 1999).

The subtlety of the hysteresis between disturbance and recovery was not detected with the linear discriminant model that showed no bias toward extreme 
classifications. With the linear discriminant analysis, most samples undergoing remediation were classified as either moderate or light usage with one sample being classified as reference. Since this analysis was linear and only used 17 descriptor variables, the resultant predictions may be of a more general nature, whereas the ANN used the complete matrix in which to base predictions. Regardless, the predictions of the linear analysis could be accepted and used to aid stakeholders in management of the land use.

\section{Conclusions}

The goal of this project was to explore the possibility of using the soil microbial community as an ecological indicator signaling the degree of environmental degradation along a disturbance gradient. The analysis based on the soil PLFA was successful, reflected above-ground changes, and provided an index of the degree of land disturbance (traffic) the soil received. Both linear discriminant and non-linear ANN analysis were able to adequately classify the degree of disturbance. However, there were drawbacks when the ANN and linear discriminant models were used to predict stages of soil recovery in remediated transects. The linear discriminant model was shown to be a fairly robust but perhaps coarse measure of remediative efforts, and the ANN was sufficiently sensitive to detect subtleties in recovery not detected with the linear discriminant analysis, but in current form could not be relied on to classify remediated samples. The inclusion of data reflecting remediation in these models could possibly make them capable of monitoring a more complete process of soil degradation and recovery.

\section{Acknowledgements}

The authors would like to acknowledge the help of Suzanne Beyeler and Patty Kosky in the field and Jonas Almeida for suggestions regarding ANNs. We also thank Theresa Davo for reviewing this manuscript. The project was funded by a contract from the Conservation Program of the Strategic Environmental Research and Development Program (SERDP) with Oak Ridge National Laboratory (ORNL) under subcontract
4500012011, Indicators of Ecologica Change. ORNL is managed by UT-Battelle, LLC for the US Department of Energy under contract DE-AC05-00OR22725.

\section{References}

Alexander, D.B., 1998. Bacteria and Archaea. In: Sylvia, D.M., Fuhrmann, J.J., Hartel, P.G., Zuberer, D.A. (Eds.), Principles and Applications of Soil Microbiology. Prentice Hall, NJ, pp. 65-66.

Balkwill, D.L., Leach, F.R., Wilson, J.T., McNabb, J.F., White, D.C., 1988. Equivalence of microbial biomass measures based on membrane lipid and cell wall components, adenosine triphosphate and direct counts in subsurface aquifer sediments. Microb. Ecol. 16, 73-84.

Bligh, E.G., Dyer, W.J., 1954. A rapid method of total lipid extraction and purification. Can. J. Biochem. Physiol. 37, 911917.

Blum, W.H., 1998. Basic concepts: degradation, resilience, and rehabilitation. In: Lal, R., Blum, W.H., Valentine, C., Stewart, B.A. (Eds.), Methods for Assessment of Soil Degradation. CRC Press, Boca Raton, Florida.

Borga, P., Nilsson, M., Tunlid, A., 1994. Bacterial communities in peat in relation to botanical composition as revealed by phospholipid fatty acid analysis. Soil Biol. Biochem. 26, 841848.

Bossio, D.A., Scow, K.M., 1998. Impacts of carbon and flooding on soil microbial communities: phospholipid fatty acid profiles and substrate utilization patterns. Microb. Ecol. 35, 265-278.

Boylen, C.W., Ensign, J.C., 1970. Long-term starvation survival of rod and spherical cells of Arthrobacter crystallopoietes. J. Bacteriol. 103, 569-577.

Dale, V.H., Beyeler, S., 2001. Identifying ecological indicators of change along an anthropogenic disturbance gradient within a long-leaf pine habitat. Ecological Indicators (review).

Garten, C.T.Jr., Ashwood, T.L., Dale, V.H., 2001. Soil carbon and nitrogen as ecological indicators of change along an anthropogenic disturbance gradient. Ecological Indicators (review).

Guckert, J.B., Antworth, C.P., Nichols, P.D., White, D.C., 1985. Phospholipid, ester-linked fatty acid profiles as reproducible assays for changes in prokaryotic community structure of estuarine sediments. FEMS Microbiol. Ecol. 31, 147-158.

Gunstone, F.D., Herslöf, B., 1992. A Lipid Glossary. Oily Press, Dundee, p. 101.

Keynan, A., Sandler, N., 1983. Spore research in historical perspective. In: Hurst, A., Gould, G.W. (Eds.), The Bacterial Spore, Vol. 2. Academic Press, New York, pp. 1-48.

Kirchner, M.J., Wollum, A.G., King, L.D., 1993. Soil microbial populations and activities in reduced chemical input agroecosystems. Soil Sci. Soc. Am. J. 57, 12891295.

Lee, K.E., 1991. The diversity of soil organisms. In: Hackworth, D.L. (Ed.), The Biodiversity of Microorganisms and Invertebrates: Its role in sustainable agriculture. 
CASA-FA Report, Series 4, Redwood Press Ltd., England, pp. 72-89.

Macnaughton, S.J., Stephen, J.R., Venosa, A.D., Davis, G.A., Chang, Y.-J., White, D.C., 1999. Microbial population changes during bioremediation of an experimental oil spill. Appl. Environ. Microbiol. 65, 3566-3574.

Myers, R.T., Zak, D.R., White, D.C., Peacock, A.D., 2001. Landscape-level patterns of microbial community composition and substrate use in upland forest ecosystems. Soil Sci. Soc. Am. J. 65, 359-367.

O’Leary, W.M., Wilkinson, S.G., 1988. Gram-positive bacteria. In: Ratledge, C., Wilkinson, S.G. (Eds.), Microbial Lipids, Vol. 1. Academic Press, London, pp. 117-201.

Peacock, A.D., Mullen, M.D., Ringelberg, D.B., Tyler, D.D., Hedrick, D.B., Gale, P.M., White, D.C., 2001. Soil microbial response to dairy manure or ammonium nitrate applications. Soil Biol. Biochem. 33, 1019-1101.

Paul, E.A., 1984. Dynamics of organic matter in soils. Plant Soil 76, 275-285

Pinkart, H.C., Ringelberg, D.B., Piceno, Y.M., Macnaughton, S.J., White, D.C., 2000. Biochemical approaches to biomass measurements and community structure. In: Hurst, C.H., Knudsen, G.R., McInerney, M.J., Stetzenbach, L.D., Walter, M.V. (Eds.), Manual of Environmental Microbiology, 1st Edition, American Society for Microbiology Press, Washington, DC, pp. 91-101.

Rice, C.W., Moorman, T.B., Beare, M., 1996. Role of microbial biomass carbon and nitrogen in soil quality. In: Doran, J.W., Jones, A.J. (Eds.), Methods for Assessing Soil Quality. Special Publication no. 49, SSSA, Madison, Wisconsin, USA, pp. 203-215.

Stephen, J.R., Chang, Y.J., Gan, Y.D., Peacock, A.D., Pfiffner, S.M., Barcelona, M.J., White, D.C., Macnaughton, S.J., 1999. Microbial characterization of a JP-4 fuel-contaminated site using a combined lipid biomarker/polymerase chain reaction- denaturing gradient gel electrophoresis (PCR-DGGE)-based approach. Environ. Microbiol. 1 (3), 231-241.

Tisdall, J.M., Oades, J.M., 1982. Organic matter and water stable aggregates in soils. J. Soil. Sci. 33, 141-163.

Verma, J.N., Khuller, G.K., 1983. Lipids of Actinomycetes. Adv. Lipid Res. 20, 257-310.

White, D.C., Bobbie, R.J., Heron, J.S., King, J.D., Morrison, S.J., 1979. Biochemical measurements of microbial mass and activity from environmental samples. In: Costerton, J.W., Colwell, R.R. (Eds.), Native Aquatic Bacteria: Enumeration, Activity, and Ecology, ASTM STP 695. American Society for Testing and Materials, Philadelphia, PA, pp. 69-81.

White, D.C., Stair, J.O., Ringelberg, D.B., 1996. Quantitative comparisons of in situ microbial biodiversity by signature biomarker analysis. J. Indust. Microbiol. 17, 185-196.

White, D.C., Ringelberg, D.B., 1998. Signature Lipid Biomarker Analysis. In: Burlage, R.S., Atlas, R., Stahl, D., Geesey, G., Sayler, G. (Eds.), Techniques in Microbial Ecology. Oxford University Press, New York, pp. 255-272.

White, D.C., Flemming, C.A., Leung, K.T., Macnaughton, S.J., 1998. In situ microbial ecology for quantitative appraisal, monitoring, and risk assessment of pollution remediation in soils, the subsurface and in biofilms. J. Microbiol. Methods 32, 93-105.

Wilkinson S.G., 1988. Gram-negative bacteria. In: Ratledge, C., Wilkinson, S.G. (Eds.), Microbial Lipids, Vol. 1. Academic Press, London, pp. 299-489.

Zak, J.C., Wilig, M.R., Moorhead, D.L., Wildman, H.G., 1994. Functional diversity of microbial communities: a quantitative approach. Soil Biol. Biochem. 26, 1101-1108.

Zogg, G.P., Zak, D.R., Ringelberg, D.B., Macdonald, N.W., Pregitzer, K.S., White, D.C., 1997. Compositional and functional shifts in microbial communities due to soil warming. Soil Sci. Soc. Am. J. 61, 475-481. 